\title{
Second Degree Relative
}

National Cancer Institute

\section{Source}

National Cancer Institute. Second Degree Relative. NCI Thesaurus. Code C19811.

Any relative who is two meioses away from a particular individual in a family; a relative with whom one quarter of an individual's genes is shared (i.e., grandparent, grandchild, uncle, aunt, nephew, niece, half-sibling) (from Genetics Home Reference glossary) 